\title{
Map showing the late preglacial (Teays-age) course and pre-mlinoian deposits of the Licking River in north-central Kentucky
}

\author{
Stanley J. Luft
}

\section{INTRODUCTION}

\section{Historical background}

A considerable body of writing exists on the geological evolution of the Ohio River and some of its principal tributaries, among which is the Licking River of Kentucky (fig. 1).

There is general agreement, from the earliest workers onward, that the Ohio River, as we know it today, did not exist as a throughgoing stream until Pleistocene time. The early work of Fowke (1898), Leverett (1902), and Tight (1903) demonstrated that, prior to the formation of the Ohio River, the preglacial Licking River of Kentucky flowed northward along the present Mill Creek valley through present-day Cincinnati, and that it joined the preglacial Kentucky River near Hamilton, Ohio. The ancient course of the Licking in southwestern Ohio, although completely buried by glacial material, has been delineated by studies of numerous deep wells that penetrated glacial material into bedrock. The hypothesis of northeastward flow of the preglacial Kentucky River, long favored by some earlier workers (Fowke, 1898, 1900, 1924, 1933; Malott, 1922; Durrell, 1961) and opposed by others (Fenneman, 1914, 1916; Leverett, 1929; Stout and others, 1943; Hays, 1951; Walker, 1957) has been satisfactorily demonstrated in recent years (Swadley, 1971; Teller, 1973; Ray, 1974; Dury and Teller, 1975). The two streams joined near Hamilton to form the northeast-flowing Hamilton River (fig. 2). The Hamilton River, whose valley is now closely followed by the southwest-flowing Great Miami River, was a major tributary of the TeaysMahomet river system of Horberg (1945) and Wayne (1952).

In northernmost Kentucky and southwestern Ohio, fluvial deposits of the preglacial Licking River are complexly involved with glacial and glaciofluvial deposits of several ages. Evidence for the former course of the stream in that region is limited to well records, and to the abandoned valleys and underfit streams that so intrigued the early workers of the region.

South of the glacial boundary, the course is more easily followed, being marked by locally extensive exposures of high-level fluvial deposits containing appreciable quantities of gravel. These gravel deposits, originally described by Squier (1883), were first recognized as river gravels by Miller (1895). Few studies have since been made on the distribution of the ancient fluvial deposits and their bearing upon the history of the Licking River. Major exceptions were Desjardins (1934) and Durrell (1961). Their findings and conclusions, although based upon very limited field work, differ only in detail from those of this report.

The purposes of this report are: (1) To summarize and unify the published and unpublished results of new mapping in north-central Kentucky that pertain to the deposits and the development of the Licking River. (2) To place the above observations within a regional perspective, thereby modifying to some extent the conclusions of earlier workers. (3) To adopt and name a mapped unit, the Claryville Clay, for use by the U.S. Geological Survey. (4) To identify some still unresolved problems that relate to the development of the Licking River.

\section{Methods of study}

Licking River deposits were studied during the course of geological mapping by the U.S. Geological Survey, in cooperation with the Kentucky Geological Survey. About 190 kilometers (117 miles) of the meandering preglacial river channel and its deposits were delineated and mapped at a scale of $1: 24,000$ by A. B. Gibbons and this author. The downstream deposits (Alexandria, New Richmond, and Newport and Withamsville quadrangles) were mapped by Gibbons between 1967 and 1971. This author mapped the deposits in the Covington quadrangle, and from the De Mossville quadrangle as far upstream as Blue Licks Spring in northeastern Nicholas County (Cowan quadrangle) between April 1968 and June 1974. Additional field checks in certain critical areas were made in September and October 1976. L. V. Blade extended the mapping from Blue Licks Spring to the south edge of the Cowan quadrangle during 1977.

The course of the preglacial Licking River shown on the map was determined from the cited geologic quadrangle (GQ) maps, through the construction of numerous cross-sections, and through contouring to locate the thalweg ( $a$ line connecting the lowest points along the bedrock floor of the river). The course of the preglacial Licking River and contemporaneous rivers in southwestern Ohio is shown on figure 2. Information pertaining to the Pleistocene and modern channels of the river was obtained from subsurface logs on file at the City Engineer's Office, Covington, Kentucky, from Paul Ryder (unpub. data, U.S. Geological Survey, Louisville, Kentucky), and from Durrell (1961), Price (1964), and Walker (1953).

The preglacial stream profile (fig. 3) was drawn, on a quadrangle-by-quadrangle basis, through the lowest gravel-bedrock contacts observed. Elevations 
that appeared to be anomalously low were generally discarded, on the assumption that they represent base of colluvium, soil creep, or gravel float, induced by recent exhumation and erosion of the original valley floor. Some of the low elevations, however, may not be anomalous, as bedrock floors of valleys are by no means smooth, and are subject to local scouring.

\section{Acknowledgments}

A. B. Gibbons encouraged the writer to prepare this report. The map, figures, and text have benefitted greatly from discussions with, and critical reviews by E. R. Cressman, A. B. Gibbons, K. L. Pierce, W C Swadley, and J. W. Whitney.

\section{SETTING, DESCRIPTION, AND AGE OF THE DEPOSTTS}

The development of the Licking River has been episodic, in response to geologic events that sometimes took place outside its drainage basin. Its history can be inferred from a study of the various deposits it left behind, and from their topographic position. The deposits and their setting (fig. 4) are described below; ages assigned to the deposits are tentative or approximate except where noted.

\section{Deposits on the upland surface in Campbell County}

Scattered deposits of silt, clay, fine sand, and minor fine gravel are present in Campbell County, Kentucky along the upland surface that separates the present Licking and Ohio River valleys (see map). These deposits, as much as $13.5 \mathrm{~m}$ (45 ft) thick, were described by Hays (1951, p. 133), Durrell (1961, p. 74), Teller $(1962,1973)$, and Gibbons $(1971,1973)$. They lie at altitudes ranging between 240 and $270 \mathrm{~m} \mathrm{(785} \mathrm{and}$ $885 \mathrm{ft}$ ) above sea level. The deposits, present chiefly at Alexandria and Cold Spring, were mapped by Gibbons $(1971,1973)$ as high-level silt and sand deposits of Tertiary or Quaternary age.

The deposits are dark yellowish orange $(10 \text { YR } 6 / 6)^{1}$ and dark to moderate yellowish brown (10 YR $4 / 2-5 / 4)$. They are leached, deeply weathered, and stained with iron and manganese oxides. There is a general fining-upward tendency from medium and fine sand at and near the base to very fine sand, silt, and clay towards the top. Very fine chert and quartz gravel is locally present near the base. The deposits are massive in appearance and are nonfosiliferous. Banded lacustrine(?) clay beds are locally present beneath sand at some exposures (Teller, 1962).

Lag gravel, to $3.8 \mathrm{~cm}$ across, is present in the vicinity of the deposits (Durrell, 1961, p. 74; Teller, 1962), but little more than minor pea-size gravel is found in place. According to Durrell (1961) and Teller (1962), the lag and in-situ gravels consist of siltstone, quartz, and chert pebbles, of limonite pellets, and of silt and sand cemented by limonite. More than 90 percent of the sand fraction consists of quartz, much of it iron-stained. The bulk of the quartz is subangular

1/Goddard, E. N., chm. and others, 1948, Rock-color chart: Washington, D. C., National Research Council (reprinted by Geological Society of America, 1963), $6 \mathrm{p}$. to angular; rounded and frosted grains are rare. The remaining sand fraction consists of chert, white mica, magnetite, kaolinized feldspar, garnet, and zircon(?).

Unlike similarly situated upland deposits in northern Kenton County, west of the Licking River, which exhibit definite glaciofluvial characteristics and are of pre-Tllinoian glacial age (Brand, 1934; Schaber, 1962; Luft, 1971b), the upland deposits of Campbell County are of uncertain source, origin, and age. Teller (1973, p. 3679$)$ lists and briefly discusses five possible modes of origin, glacial outwash among them. Of these, the most probable may be Teller's third possibility, that they are Tertiary(?) river-channel sediment. This agrees with Durrell's (1961, p. 47) conclusion. If this assumption is correct, then the deposits could represent an early ancestral stage in the Licking River's history.

Lag gravel associated with accordant flat-topped spurs

Small pebbles of rounded to subrounded quartz and minor chert occur at numerous localities at elevations well above the present-day Licking River and its Teays-age predecessor (see below) and beyond the lateral limits of their respective valleys. Except in the southeasternmost part of the study area, this gravel is now found almost exclusively only near the heads of hollows, and was undoubtedly reworked from deposits that once were present upon the surface being dissected by these hollows. The dissected surface, intermediate between the upland surface and the Parker strath (see below) is generally demarked by accordant flat-topped spurs that lie about 32 to $58 \mathrm{~m}$ $(110$ to $190 \mathrm{ft})$ above the incised Teays-age paleochannels of the Licking River and South Fork.

The only in-situ gravels assigned to this unit occur near the boundary of the Piqua and Cowan quadrangles, north and northwest of Blue Licks Spring. There, scattered ridgetop exposures of fine quartz and chert pebbles are present at and slightly below $250 \mathrm{~m}(820 \mathrm{ft}$ ) above sea level, and may have been let down from slightly higher former elevations.

By projection of presumed gradients, the lag gravel associated with accordant spurs is somewhat lower, and can be considered as being a younger deposit than the upland silt and sand present further downstream in Campbell County.

\section{Teays-age fluvial deposits}

The Teays-age valley (Parker strath of Butts, 1904) of the Licking River is delineated by discontinuous patches of sediment shown on the geologic quadrangle maps as high-level fluvial deposits of Pliocene(?) and Pleistocene age.

Desjardins (1934), Durrell (1961), and Teller (1973) have satisfactorily demonstrated that this stage in the evolution of the Licking River occurred while the river was tributary, via Hamilton, Ohio, to the Teays portion of the Teays-Mahomet River of Horberg (1945) and Wayne (1952). The Teays River was defined by Tight (1903) from exposures of fluvial deposits in West Virginia, and the term "Teays" soon was applied by most cited workers to similar deposits, and as an informal age term for the deposits, elsewhere within the preglacial Teays-Mahomet system. Well-preserved segments in Pennsylvania of the strath terrace upon 
which these deposits lie were termed the Parker strath by Butts (1904). The terms "Teays age or stage", and "Parker strath or stage", have often been used interchangeably and are generally considered to represent the same level of river downcutting and filling. The two terms were extended to northern Kentucky by Desjardins (1934).

The average gradient of the Teays-age river within the study area, as determined from figure 3, was $17 \mathrm{~cm} / \mathrm{km}(0.94 \mathrm{ft} / \mathrm{mi})$, based upon a drop of $33.5 \mathrm{~m}(110 \mathrm{ft})$ over a channel distance of $190 \mathrm{~km}$ $(117 \mathrm{mi})$. The present average gradient within this same area is $26.6 \mathrm{~cm} / \mathrm{km}(1.4 \mathrm{ft} / \mathrm{mi})$, based upon a drop of $38 \mathrm{~m}(125 \mathrm{ft})$ over a channel distance of $143 \mathrm{~km}$ (89 mi). Excluded from these computations are the lowest 14 kilometers $(8.6$ miles) of the modern river channel, which were deeply scoured during the Deep Stage (see below) and are graded toward the modern Ohio River. Within northern Kentucky, the Teays-age river followed a longer and more circuitous route than does the modern river.

The Teays-age gradient is in line with those obtained for larger, contemporaneous paleorivers of the Teays-Mahomet system (table 1).

A number of large meander scars are shown on the map. Some lie as much as $10 \mathrm{~m}(35 \mathrm{ft})$ above the presumed Teays-age throughgoing channel shown on the map. The meanders were abandoned in earlier Teays time as the river continued to entrench at successively lower elevations. Several other meander scars, however, are similar in extent and thalweg altitude to adjoining throughgoing segments. It is possible that, during severe floods, both channels were simultaneously occupied by the river, and that temporary islands were left between them. At varying times one or another of the segments, and also entire segments of a meander belt, were suddenly and perhaps permanently abandoned through the process of avulsion (the sudden abandonment of meanders and channel segments, caused by floods or by other forces which change the course of a stream). Avulsion was aided by downriver glacial and interglacial events, but it is probable that avulsion also took place in preglacial times.

The readily recognizable and connectable paleochannel in most of the study area becomes poorly discernible downriver from the north-central part of the New Richmond quadrangle. The paleovalley in this northern area has been strongly dissected by tributary streams of the Ohio and Licking Rivers, and most of the Teays-age deposits have been stripped away. Evidence for this segment of the paleochannel consists of (1) isolated remnants of fluvial deposits west of Fourmile Creek, at Low Gap, and above Pooles Creek, and (2) a slightly higher channel, interpreted as a cutoff meander, filled with Illinoian Drift and lacustrine deposits, that must have formed in pre-Illinoian time. At each of the Fourmile Creek, Low Gap, and Pooles Creek localities, the gravel present (some of it as much as $12 \mathrm{~cm}$ across) is characteristically of Licking River type and locally also of Manchester River type (both described below), establishing the former presence of the throughgoing Licking River at or close to these localities. The deposits and their basal gravel lie approximately at Teays levels (the Low Gap deposits were presumably let down slightly). It is unlikely, from the abundance and local coarseness of basal gravel, that the deposits at these localities were reworked from a pre-Teays river, as the previously described older deposits are not known to contain coarse gravel.

An alternate route for the Teays-age Licking River in northern Campbell County has been proposed by, among others, Durrell (1961, fig. 2) and Teller (1973, fig. 2). It is shown on the map, in modified form, by a + symbol. It did not go through Low Gap, but stayed near the present Ohio River in the northern part of the study area where it followed the lower part of the ancestral Little Miami River to the upper part of the modern Mill Creek valley, via the Norwood Trough (fig. 2). Part of the course of this possible alternate route is indicated on the Ohio side in the northern part of the New Richmond quadrangle, by a bench (or possible strath terrace) at an altitude of about 190 . $(620 \mathrm{ft})$. The bench, only locally directly upon bedrock, is generally covered by Illinoian Drift (not mapped on the Ohio side). During a cursory oneday examination, Gibbons and this author failed to find Licking-Meschester type gravel upon, near, or below this bench. Its pre-Illinoian age, however, is unquestioned.

The alternate course may have been occupied by the Licking-Manchester River (or the forming Ohio River) at some time during the pre-nlinoian. However, direct evidence, in the form of deposits of fluvial gravel, is facking. This author favors a reconstruction of the Teays-age Licking that flowed along the Fourmile Creek-Low Gap-Pooles Creek course, leaving behind fluvial deposits of Licking-Manchester type at approximate Parker-strath altitudes. Low Gap, which lies along this course, was not, as suggested by Durrell (1961) and Teller (1973), the locus of a northeastflowing tributary of the alternate route. The gravel there is too coarse and too "Licking" in composition to have been derived by erosion and redeposition from the older deposits on the upland surface, and more likely was deposited by the throughgoing river.

Fluvial deposits of Teays age consist of highly variable proportions of silt, clay, gravel, and sand, listed in decreasing apparent abundance. The eroded remnants are as much as $8 \mathrm{~m}(25 \mathrm{ft})$ thick near Blue Licks Spring and thicken irregularly downriver to at least $22 \mathrm{~m}(75 \mathrm{ft})$ in the Falmouth quadrangle. They may be thicker further downriver where they lie beneath younger lacustrine deposits. They are deeply weathered, mostly unconsolidated, and easily eroded; locally they have been weakly to moderately cemented with limonitic material. The deposits generally are crudely bedded or lack recognizable bedding. Weathering colors range from yellowish orange (10 YR 6-8/6) and pale grayish orange (10 YR 8/4) to light and moderate brown (5 YR 6-4/4).

Gravel is mainly concentrated at and near the base of the deposits. Bedload deposits along the thalweg consist of 1.2 to $2 \mathrm{~m}$ ( 4 to $6.5 \mathrm{ft}$ ) of gravel (decreasing irregularly upriver) in a sandy to clayey matrix. Proportions of the constituent size grades are highly variable, and the gravel fraction is generally poorly sorted though locally it is moderately well sorted. Within the study area, the average grain size of bedload gravel decreases only slightly downriver. Exposures of unweathered clay in the gravel matrix are extremely uncommon; the fresh-appearing clay is only a few centimeters thick, medium bluish gray (5 B $5 / 1$ ) to greenish gray (5 G 6/1), plastic, and silty. The basal gravel-rich zone generally grades upward into an 
ill-defined gravelly sand and sandy gravel zone and then to clayey silt with sparse pebbles.

Locally, sand rather than gravel is the major coarse constituent of the deposits. Although gravel is sparse in the upper half of the deposits, fine gravel is not uncommonly found at varying elevations wherever the valley fill extends toward the valley walls. This high gravel occurs as much as $30 \mathrm{~m}$ above the elevation of the thalweg; it consists mainly of limonite and limonitized siltstone of largely local derivation. Although obscured by weathering and by poor exposures, sharp contrasts exist between gravel-rich zones, sand-rich zones, and largely silty zones, and are suggestive of scour-and-fill features.

At one locality in northwesternmost Nicholas County, $4.6 \mathrm{~km}$ west-southwest of Piqua, crudely interbedded sets of gravel-rich and gravel-poor layers, in a matrix of iron-stained sand and silt, were exposed in a fresh cut. The layers, 15 to $30 \mathrm{~cm}$ thick, lie south of the present Licking River and about $12 \mathrm{~m}$ ( $40 \mathrm{ft}$ ) above the approximate thalweg of a cutoff meander. This exposure strongly resembles examples of overbank flood deposits of bedload material described by Costa (1974) and Ritter (1975).

No fossils have been found in Teays-age Licking River deposits. S. P. Hildreth (quoted in Tight, 1903, p. 58) reported the presence of the fresh-water clam Unio in sand and gravel of a Teays-age tributaryvalley floor near Barlow, Washington County, Ohio; wells dug at this locality penetrated tree branches, wood fragments, and leaves.

The gravel and sand fractions of Teays-age fluvial deposits are described below:

Gravel-The gravel fraction consists of varying proportions of:

(a) Locally derived slabs and chips (cobble to pebble size) of limestone and siltstone, granules and pebbles of limonitized siltstone and limonite, and small cobbles and pebbles of limonitecemented sand and fine pebbles of various materials.

(b) Exotic pebbles, cobbles, and boulders brought in from a more distant upriver source area. The exotic fraction consists of, in estimated decreasing order of abundance:

1. Dark-reddish-brown ( $10 \mathrm{R} 3 / 4)$, brownish, and reddish jasperoid chert, subrounded to subangular, subequant, uniform in texture, generally less than $12 \mathrm{~cm}$ but as much as $30 \mathrm{~cm}$ in diameter; derived from the Newman Limestone of Mississippian age, particularly from its St. Louis Limestone Member.

2. Yellow, white, and pink quartz, well-rounded to subrounded, subspherical to elongate, mainly less than $1.5 \mathrm{~cm}$ but as much as $6.5 \mathrm{~cm}$ in maximum dimension; derived from the Lee Formation of Late Mississippian and Pennsylvanian age.

3. Very fine to medium-grained quartzose sandstone and quartz-matrix pebble conglomerate; weathered, indurated and case-hardened to friable, subrounded to subangular cobbles and pebbles, generally less than $15 \mathrm{~cm}$ across, local boulder-size bedding-plane slabs as much as $1 \mathrm{~m}$ across; derived from the Lee Formation. Large sandstone slabs are present at least as far downriver as southernmost Campbell County (Luft, 1972a), and as much as $11 \mathrm{~m}$ (35 ft) above the elevation of the thalweg. They were probably rafted downstream by floods, entangled in the roots of floating trees.

4. Moderate-yellowish-brown (10 YR $+5 / 4)$ flinty chert, locally fossiliferous, mostly subangular and subtabular, as much as $20 \mathrm{~cm}$ across; scarce below Piqua, but becomes increasingly abundant upstream, and is a major exotic component between Piqua and Blue Licks Spring; derived from the Brassfield Formation of Early Silurian age.

5. Siltstone and very fine to fine-grained weathered sandstone, grayish-orange (10 YR 7/4) to dusky-yellow (5 $Y$ 6/4), in subangular, tabular slabs as much as $15 \mathrm{~cm}$ across; frequency and distribution same as (4), above; derived mainly from the Farmers Member (Lower Mississippian) of the Borden Formation, and possibly from some Upper Ordovician units.

6. Silicified limestone, commonly coralline, and scarce silicified and leached dolomite, subangular, subequant, generally less than $12 \mathrm{~cm}$ across; derived from various units, including the Newman Limestone and Brassfield Formation, and the Middle Devonian Boyle Dolomite and Upper Ordovician Bull Fork Formation.

7. Pale-reddish-brown (10 $\mathrm{R} \quad 6 / 4)$ bleached porous chert, subangular, tabular; size range similar to (1), above; derived from the Newman Limestone, particularly from its St. Louis Limestone Member.

8. Rounded coal pebbles derived from the Breathitt Formation of Pennsylvannian age or from the Lee Formation of Mississippian and Pennsylvanian age. Throughout the study area coal pebbles are extremely rare constituents of the Teays-age to modern fluvial deposits of the Licking River. This contradicts the emphasis placed upon coal as a significant constituent by some workers, including Hays (1951), Durrell (1961), and Teller (1973).

Limonite pebbles and small cobbles and limonitic siltstone chips and small slabs are the most common types of gravel in the upper part of the deposits and, along with gravel derived from local limestone bedrock, are the only coarse particles present in highlevel fluvial deposits of minor paleotributary streams.

Locally derived gravel may have been carried only a few centimeters or as much as several kilometers before destruction by abrasion. The Farmers Member of the Borden Formation and older units are presently exposed along the Licking River within 40 kilometers (in a straight line) upriver from Blue Licks Spring (McDowell, 1976). The Newman Limestone and Lee Formation are exposed about 20 kilometers further upriver (Hylbert and Philley, 1971). During Teays time, source rocks were less deeply eroded than now, and would have cropped out nearer to the study area.

Sand-Sand, like gravel, is most common in the lower half of the deposits. It is generally more common than 
gravel in the upper half but much less abundant than silt and clay, which predominate in the upper half of the deposits.

A representative sample of sand was collected south of Falmouth from a sand and gravel lens estimated to lie about $20 \mathrm{~m}$ above the thalweg. The sand fraction is nearly 99 percent quartz, very fine to medium-grained, poorly sorted, mainly subangular to angular, colorless to pinkish, and iron stained. Euhedral to subhedral terminated prisms are common as grain overgrowths. Minor constituents include chert, colorless mica, limonite pseudomorphs after magnetite, and kaolinized feldspar(?).

In many Teays-age deposits elsewhere, sand is locally moderately well sorted. Grain size increases irregularly upriver. Coarse quartz sand is somewhat less angular than the finer grades, and some subrounded quartz sand is frosted and pitted. The most likely source of quartz sand was the Lee Formation.

The time during which the Teays-(Parker-) age Licking River was incised and entrenched below the upland surface in north-central Kentucky, cannot be precisely dated. Incision may have begun in late Pliocene time. It ended when the Teays-Mahomet system was blocked and disrupted by the first major Pleistocene glaciation (Nebraskan?) that advanced across Indiana and central Ohio (Ray, 1974). Within part of the study area, fluvial deposits of Teays age are overlain by fine-grained sediments deposited in an ice-marginal lake that formed when a glacier blocked the Licking River in the Cincinnati area during early Pleistocene time.

\section{Claryville Clay}

From north of Butler to the northwestern part of the New Richmond quadrangle the high-level fluvial deposits of Teays age are almost completely buried under as much as $12 \mathrm{~m} \mathrm{(40} \mathrm{ft)} \mathrm{of} \mathrm{horizontal,} \mathrm{poorly}$ resistant, finely laminated to thinly bedded lacustrine clay shale and thin interbeds of limonitized siltstone.

These sediments were named the Claryville clays by Durrell (1961, p. 72-73), for exposures at and near the type locality of Claryville, Campbell County, Kentucky (Alexandria $71 / 2$ minute quadrangle). The unit is herein adopted for use by the U.S. Geological Survey as the Claryville Clay, of early Pleistocene (Nebraskan or Kansan) age. There are no satisfactory sections to serve as type or reference sections.

Fresh exposures are rare, and found only in recent artificial cuts and along actively eroding streams. The least oxidized clay is light bluish gray (5 B $7 / 1)$ and greenish gray $(5 \mathrm{G} 6 / 1)$ when moist, but weathers readily through olive gray $(5 Y$ 5/2-2-4/1) and brownish gray (5 YR 4/1) to moderate yellowish brown (10 YR 5/4), light brown (5 YR 5/6) and moderate brown (5 YR 4/4) (all colors moist). (Similar pre-Illinoian lake clays west of Cincinnati consist mainly of illite and of expandible illite-montmorillonite and chlorite-vermiculite clay minerals (Ettensohn, 1974.) Fresh clay is plastic, slightly silty in part, and, according to Durrell (1961, p. 73) contains approximately 20 percent calcium carbonate. In normal weathered exposures, clay is leached of carbonate material for observed depths in

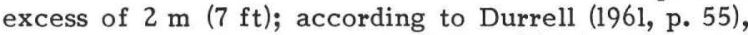
depths of leaching may exceed $5 \mathrm{~m}(16 \mathrm{ft})$. Limonite cements thin interbeds of argillaceous siltstone. Gravel associated with the deposits consists of pebbles and small chips of locally derived limonite, siltstone, and limestone.

The Claryville Clay was deposited within a temporary proglacial finger lake informally called Lake Claryville. The lake formed when the lower part of the Teays-age Licking River in Kentucky was ponded by a dam of ice and drift (Wright, 1884, p. 27-28) or outwash to the north and south of Cincinnati.

The northern part of the Claryville Clay includes glacial flour that is the source of the contained calcium carbonate. The unit grades southward into fluvial deposits and loses its identity near Butler. It is likely that, upstream from Butler, fluvial deposition of late Teays age was contemporaneous with slackwater deposition downstream from Butler. The Claryville Clay, therefore, is a mixture of downstream-derived glaciolacustrine sediment and of upstream-derived fluvial sediment. No erratics of northern derivation were found in the Clayville Clay.

The Licking River may also have been blocked by a valley train of the newly-forming, ice-marginal Ohio River (see below). This could have caused slackwater deposition in the northern part of Lake Claryville, as took place during Wisconsin time (see below) along the Licking River and other tributaries of the Ohio River. An outwash dam, rather than one of drift or ice, would explain the apparent absence of ice-rafted erratics in the Claryville Clay.

Tributary stream sediments and possible deltaic deposits are locally present within some arms of the former lake. At one such locality in the northwestern part of the Butler $71 / 2$ minute quadrangle, a possible strand line is present at about $233 \mathrm{~m}(760$ to $770 \mathrm{ft}$ ) altitude (Luft, 1972a). It consists of thin zones of sparse fine gravel of local derivation within weathered clay and is indicative of a fluctuation in lake level.

Isolated patches of deeply weathered fine-grained sediments, presumably in part lacustrine, are present beyond the main body of the unit (fig. 4 and map), as in the De Mossville and Goforth quadrangles (Luft, 1970; 1971a). They are tentatively assigned to the Claryville Clay.

No macrofossils have been found in the unit. Ettensohn (1974) reported the rare presence of pollen and spores, without specifying locations, in pre-Illinoian lacustrine clays of the Cincinnati region. Isolated exposures of the Claryville Clay are present at altitudes as high as $260 \mathrm{~m}$ (850 ft) (Gibbons, 1971), nearly $70 \mathrm{~m}(230 \mathrm{ft})$ above the Teays-age thalweg. The altitude of the lowest present-day cols along the divide between the Licking and Kentucky River basins south of glaciated northernmost Kentucky is at least $275 \mathrm{~m}$ $(900 \mathrm{ft})$. The lake surface therefore could have been as high as about $275 \mathrm{~m}$ (900 ft) (Leverett, 1929, p. 46; Fenneman, 1938, p. 303-304). This figure is only slightly below the maximum altitude $(280 \mathrm{~m}$, or $920 \mathrm{ft})$ of pre-Illinoian outwash in the Covington quadrangle (Luft, 1971b)--the outwash which probably represents the remaining portion of the glacial (or glaciofluvial) dam that impounded Lake Claryville.

Similar ice-marginal, slackwater lakes formed, probably contemporaneously, elsewhere within the Teays system and particularly east of Cincinnati. They include the extensive former Lake Tight of southern Ohio (Goldthwait and others, 1967), and 
proglacial lakes in West Virginia (Rhodehamel and Carlston, 1963; Neff and others, 1970). The similarly non-fossiliferous Minford Silt accumulated in Lake Tight (Stout and Schaaf, 1931) to an accordant altitude of $262 \mathrm{~m}(860 \mathrm{ft}$ ) (Ver Steeg, 1936, p. 939; Hoyer, 1977). Durrell (1961) and Ray (1974, p. 31) have correlated the Claryville Clay with the Minford Silt of southern Ohio. The Minford Silt exhibits reversed polarity and is considered by Hoyer $(1972,1977)$ to be pre-Brunhes (more than about 700,000 yrs BP) and therefore pre-Illinoian. A more precise age of the continental ice sheet that invaded the Cincinnati area and the uplands of northern Kentucky, causing the disruption and ponding of the Teays-age Licking River, remains in doubt. The Nebraskan versus Kansan controversy for this region has been discussed in detail by Durrell (1961, 1965), Goldthwait and others (1967), Leighton and Ray (1965), Ray (1965, 1974), and Teller (1973).

\section{Alluvium of valley sides and meander cores (not shown on map)}

The destruction of Lake Claryville and other ice-marginal and proglacial lakes, the northward retreat of the early Pleistocene glacier from part or all of the old, disrupted Teays-Mahomet system, and the appearance of a throughgoing Ohio River inaugurated a stage, or stages, of deep downcutting by the new master stream of the region, the Ohio River system. The term "Deep Stage" (Ver Steeg, 1936) has been applied to this period of valley development that eventually cut down to, and locally below present stream levels. The Ohio River and its tributaries rapidly entrenched themselves within new and preexisting valleys, very likely through static rejuvenation (Malott, 1920; Wayne, 1952, p. 581), far below Parker strath levels and generally below present levels. In the process, they formed channels that tended to be straighter and shorter than those of predecessor streams.

The Deep Stage has been generally assigned a pre-Illinoian age (Stout and others, 1943), and more specifically, a Yarmouthian age (Durrell, 1961). It is likely (K. L. Pierce, written communication, April 24, 1979) that is consisted of several stages of downcutting, related to base-level changes during a long interval of time. It probably began during the waning of the early Pleistocene (Nebraskan?) glacier and ended with the advent of the Illinoian Glaciation into the Central Interior Region. Much of the entrenching may have been in response to a marginal bulge associated with glacial downwarping to the north, and perhaps also to a general lowering of sea level, during times of intervening glaciations.

The Deep Stage came to an end by the time an Illinoian ice sheet reached the region from the north and northeast (Durrell, 1961; Goldthwait and others, 1967; Ray, 1974). The segment of the Ohio River, between the Little Miami River and Ivor, Kentucky (see map for location), that was carved during the Deep Stage, was occupied by Illinoian ice and partly filled by glacial deposits (Goldthwait and others, 1967; Gibbons and others, 1975; Kohut and others, 1973; Luft and others, 1973). During the Illinoian glacial maximum, the Ohio river was displaced into a proglacial bypass channel west of the Illinoian glacial boundary (see map), that closely followed and deepened the Teays-age valley of the predecessor Manchester River (Gibbons, 1973; Gibbons and others, 1975).

Outwash deposits were built southward, filling the Deep-Stage valley of Mill Creek (the Teays-age downriver continuation of the Licking River in Ohio) and extending for several kilometers up the DeepStage Licking River valley (Luft, 1971b; Gibbons, 1973; Ray, 1974). The Licking River, thus blocked by outwash near Covington and Newport, aggraded over its entire length within and for some distance upstream from the study area.

Relict channel and terrace deposits (not shown on the map) within the present (Deep Stage) valley of the Licking River and bracketed at present as post-Claryville to pre-Wisconsin in age, are found along alternate valley walls and also form the cores of many present and abandoned meanders of the river channel. A part of these deposits consists of alluvium left by the Licking River in post-Claryville time as it cut its modern valley. The bulk of the deposits, however, probably formed by aggradation as a result of damming by Illinoian outwash near the present mouth of the river. The deposits are shown as "Qam" on geologic quadrangle maps from the Claysville $71 / 2$ minute quadrangle downriver (see index map); they are thin and were not mapped further upriver.

The deposits are very similar in composition and weathering characteristics to the older and higher Teays-age deposits. The gravelly basal zone, where not concealed beneath younger sediments, appears thinner than that of the Teays-age fluvial deposits; gravel in general is finer grained and not as abundant. The relatively impoverished bedload-gravel fraction suggests that this unit was more a product of aggradation than of renewed downcutting upriver, and that a large proportion of the coarse constituents were derived and reworked from Teays-age deposits rather than from upriver bedrock. Cut-and-fill features are locally present in the lower part of some deposits, particularly in zones rich in sand.

Within the study area the deposits thicken irregularly from about $9 \mathrm{~m}(30 \mathrm{ft})$ in southern Claysville quadrangle to about $20 \mathrm{~m}(65 \mathrm{ft})$ in downstream quadrangles. They are probably masked by overlying Wisconsin terrace deposits or perhaps are absent downriver from Grants Bend.

\section{Terrace deposits (not shown on map)}

Two constructional terrace levels underlain by fluvial and slackwater clays and silts stand above the channel of the modern Licking River and its larger tributaries within the study area. Aggregate thicknesses of the deposits range from more than $28 \mathrm{~m}$ $(85 \mathrm{ft})$ in the Alexandria quadrangle to no more than $12 \mathrm{~m}(40 \mathrm{ft})$ in the Claysville quadrangle.

The older, higher, and areally more extensive terrace lies generally at elevations of between 18 and $28 \mathrm{~m}(60$ and $90 \mathrm{ft})$, decreasing upriver, above the present river bed (fig.3). Some of it lies within the reach of modern 50-yr flood crests. This terrace has been dated as Tazewell in age (time of peak Wisconsin Glaciation of the Ohio River valley) by Ray (1974) on the basis of regional correlations "substantiated by carbon-14 dates of $18,520+500$ and $19,940+300$ yrs BP for wood" (Ray, 1974, p. 58-59). The lower terrace, which is less extensive and lies 6 to $18 \mathrm{~m}$ ( 20 to $60 \mathrm{ft}$ ) 
lower (decreasing upriver), is within reach of modern 5-yr flood crests. It loses its separate identity upstream from McKinneysburg (northeastern part of Kelat quadrangle). The lower terrace, which is at least partly of Cary age, was assigned to the Cary Stade by Ray (1974, p. 64-65) on the basis of its topographic relation to the terrace of Tazewell age and on regional relationships within the Ohio River valley.

Terrace deposits of both ages consist largely of unconsolidated and easily eroded silty clay that weathers readily to pale grayish orange (10 YR 8/4) and light to moderate yellowish brown (10 YR 6-5/4). Weathering has obscured bedding characteristics, but in relatively fresh exposures, the silty clay is light greenish gray (5 G 8/1) to medium light gray (N 6) and is commonly laminated to thinly and evenly bedded. Gravel and sand are generally concentrated in the substratum (bedload and overlying lenses), and are also present near the onlap of terrace deposits onto bedrock. The deposits include the same exotic gravel components as do the older fluvial deposits, but in smaller amounts. Limestone gravel derived from local bedrock units is more abundant and generally coarser. Scour-and-fill channels are locally visible in sand and gravel of and near the substratum.

In the southern part of Covington and near Latonia (Covington quadrangle), the fluvial high-terrace deposits interfinger and grade downstream almost imperceptibly into Wisconsin outwash deposits (Price, 1964; Luft, 1971b) at and below $165 \mathrm{~m}$ altitude $(540 \mathrm{ft})$-the terrace of Tazewell age that underlies much of Covington and Newport. At several places along the lower Licking, as above Banklick Creek southwest of Latonia (Covington quadrangle), fluvial deposits grade into beds of laminated, apparently varved, lacustrine deposits consisting largely of plastic calcareous clay that is a mixture of slackwater alluvium from upstream and glacial rock flour from valley trains in the Ohio River valley.

Terrace scarps, mainly of silty clay, are commonly nearly vertical and gullied. The terraces, particularly the lower one, have been reduced and locally notched by stream erosion.

\section{Deposits of the modern stream (not shown on map)}

A modern narrow floodplain laps alternately upon terrace and older fluvial deposits and upon bedrock along the course of the present Licking River and its tributaries. It generally lies less than $5 \mathrm{~m}(17 \mathrm{ft})$ above river level and is flooded at least yearly, particularly during winter thaws and in the early spring. The poorly to moderately well sorted floodplain deposits, which are no more than $8 \mathrm{~m}$ (25 ft) thick, are similar in composition and texture to the Wisconsin fluvial deposits.

Except along its lowest 13 kilometers of the channel and during flood stage, the Licking River is a shallow stream, gently flowing on bedrock. Pools, riffles, small cascades, and point bars are the most prominent channel features. The bedload and the point bars consist largely of (1) horizontal and imbricated local limestone, shale, and siltstone gravel, ranging in size from large slabs to small chips, and (2) of the ubiquitous exotic gravel and sand, all in an unconsolidated silty to sandy matrix.

\section{MAJOR TRIBUTARIES AND THEIR DEPOSTTS}

\section{South Fork}

The South Fork is the most important tributary of the Licking River, and has a drainage area of about $2,400 \mathrm{~km}^{2}\left(927 \mathrm{mi}^{2}\right)$ (P. A. Emery, written commun., February 6, 1978). The flow is mainly to the north, and the headwaters are near and north of Winchester, in north-central Clark County, east of Lexington (fig. 1). The entire course lies within an area of limestone, shale, and minor siltstone of Middle and Late Ordovician age. The nearest exposures of younger Paleozoic rocks are east-southeast of Winchester and south of Mt. Sterling, within the drainage basin of the Kentucky River. In those areas some outcrops of chert-bearing Mississippian limestones and of quartz-pebble Pennsylvanian conglomerates are present within 20 airline $\mathrm{km}$ of some headwaters of the South Fork.

The South Fork and its preglacial deposits were mapped by this author along a channel distance of about $48 \mathrm{~km}(30 \mathrm{mi})$ from its mouth. Over this distance, the bedrock floor rises about $30 \mathrm{~m}(100 \mathrm{ft}$ ) (fig. 3), thus the gradient is $60 \mathrm{~cm} / \mathrm{km}(3.3 \mathrm{ft} / \mathrm{mi})$, several times that of the trunk stream.

In spite of being a much shorter stream than the main Licking River, within the study area-and for a considerable distance upstream-the South Fork flows within a valley that is wider than that of the main Licking River, measured at similar distances from their junction. Ancient and modern deposits of the South Fork are at least as extensive as those of the main Licking at these equivalent upstream distances from the junction. The valley width, bankfull channel width, and runoff per square mile also are greater. Seen either in the field or from topographic maps the South Fork, and not the longer main stem (the Licking River), is the more impressive stream.

The reason for the anomalously wide valley is that the South Fork, unlike the main Licking, has remained in its preglacial valley, which it has widened and incised at least since early-Teays time. Because of this imposed lateral restriction upon the fluvial deposits, no sharp distinction can generally be made between the Teays-age deposits and the locally contiguous and similar, and lower post-Teays but pre-Wisconsin alluvium of valley sides and meander cores (Luft, 1975). Local distinctions can readily be made, however, and are the basis for the thalweg elevations shown on the map and on figure 3.

Fluvial deposits of varying ages resemble one another and are also very similar to those of the main stem of the Licking River. The locally contiguous deposits of Teays age and of younger (but pre-Wisconsin) age aggregate as much as $20 \mathrm{~m}$ (65 ft) in thickness. Wisconsin-age terrace deposits are also as much as $20 \mathrm{~m}(65 \mathrm{ft})$ thick. Gravel of the Teays-age stream is present nearly $25 \mathrm{~m}$ above the presumed thalweg. Sand, which is generally more common than gravel, is present to about $30 \mathrm{~m}$ above the thalweg. Sand, present mainly in the lower part of the alluvium of valley sides and meander cores, also occurs in pockets and lenses in the upper part of these deposits. It also resembles that of the main Licking. It is very fine to coarse, poorly to moderately well sorted, and consists almost entirely of rounded to subangular iron-stained quartz; sparse grains of chert make up most of the remainder. 
The major difference between Licking and South Fork sediments is in the abundance and size of the gravel fraction. Gravel in South Fork fluvial deposits is less abundant than that in the main Licking and, except for locally derived slabs of limestone, South Fork gravel rarely exceeds $6.5 \mathrm{~cm}$ in diameter. The basal gravel-rich zones also are thinner in South Fork deposits. Gravel is composed of, in decreasing order of abundance: limonite and limonitized siltstone (to $65 \mathrm{~mm}$ ), rounded to subrounded quartz pebbles (mainly less than $15 \mathrm{~mm}$ ), subangular to subrounded reddishbrown chert (to $40 \mathrm{~mm}$ ), and rare pebbles of Mississippian coralline limestone (to $45 \mathrm{~mm}$ ). As is the case of gravel of the main Licking, part of the bedload gravel, both ancient and modern, was derived from Carboniferous sedimentary rocks. Carboniferous strata, however, are not present within the drainage basin of the South Fork.

Possible sources for the exotic gravel fraction in the Teays-age deposits of the South Fork are discussed briefly:(l) The gravel was derived from higher and older fluvial deposits such as the Irvine Formation (Campbell, 1898) or even older, no longer present, upland gravels. Jillson (1963) found Lee Formation-type pebbles (his localities 14 through 18) near headwaters of the present South Fork, at altitudes ranging between 265 and $312 \mathrm{~m}(870$ and $1,025 \mathrm{ft}$ ) above sea level. Some residual gravel could therefore have been available, probably on a limited basis, to the preglacial South Fork.(2) Outliers of Carboniferous rock were present near the headwaters as late as early Teays time. Since then, however, they must have receded at least $20 \mathrm{~km}$ to the position of the present outliers east of Winchester, a perhaps unlikely rate of erosion.(3) During Teays or more likely earlier times, the South Fork was a longer stream that drained the Carboniferous region of eastern Kentucky. This source of gravel later became unavailable, perhaps through the capture of those headwaters by the Kentucky River. An originally distant source, followed solely by reworking of the same gravel, can explain the lesser abundance and smaller size of the exotic gravel in the valley of the South Fork, compared to that of the main stem of the Licking River.(4) It has been postulated by Miller (1895) and repeated or modified on occasion by later writers up to and including Ray (1974) that, as the result of an early glacial ponding in the vicinity of Cincinnati, the South Fork became a temporary sluiceway for backed-up waters of the upper Licking River system. This reversed flow could have received gravel from the normal source areas along the main Licking River and moved them southward along the South Fork. According to this hypothesis, the waters eventually escaped over a low divide into the Kentucky River basin. This hypothesis does not fit the pattern of a normal, northward gradient of the Teays-age South Fork. It is also negated by the absence of cols as low as $285-290 \mathrm{~m}(875-900 \mathrm{ft})$ along the divide to the west, which would have permitted overflow even though in the opposite direction of the valley slope (see discussion of Claryville Clay, above); also, erratics which would be expected in an ice-dammed lake are lacking in the valley of the South Fork. The events described, however, could have taken place prior to Teays time, and the resulting gravel could have been reworked into the Teays-age deposits.
North Fork

The North Fork is a westward flowing meandering stream with headwaters in Devonian and lowermost Mississippian strata of western Lewis County, Kentucky. Along most of its course, it flows along Ordovician limestones, shales, and siltstones.

Fluvial deposits along the stream were mapped by the writer for only 20 stream km (about 7.5 airline $\mathrm{km}$ ) from its mouth. Like the larger South Fork, it occupies a wider valley (between the mouth and a point 4.5 stream $\mathrm{km}$ above Milford) than does the equivalent stretch of the Licking River, suggesting that this reach, at least, was occupied by the stream for a long period of time. The lower valleys and floodplains of this and other tributary streams, even of minor ones, are commonly-wider and locally considerably so-than the valley and floodplain of the Licking River at and near their common junctions. Beaver Creek (Luft, 1976) is another typical example of this phenomenon. The greater widths for the tributaries are attributed to the fact that these stream channels remained within-and eroded over a longer period of time-their preexisting valleys, even while the trunk stream was shifting its course.

Within the mapped North Fork reach, high-level fluvial deposits are absent, and were probably removed during an extended period of erosion. Pre-Wisconsin alluvium of valley sides and meander cores, on the other hand, forms deposits that are as thick and extensive as those of the equivalent stretch of the Licking River. Near its mouth, the valley of the North Fork is five times as wide as is the Licking River valley just upstream. It appears from the spatial distribution of fluvial deposits (Luft, 1976), that during post-Teays and pre-Wisconsin time, the junction of these two rivers lay nearly $3 \mathrm{~km}$ east of and above the present junction (see map).

Gravel of the modern stream and of its floodplain, terrace, and pre-Wisconsin deposits, upstream of that former junction, consists of pebbles and small cobbles of brown chert of Silurian age, weathered siltstone, limonitic siltstone, limestone, and limonite. Within the study area, gravel is subrounded to angular, generally only $4 \mathrm{~cm}$ or less across, and rarely as much as $7 \mathrm{~cm}$ across. Lacking are the pebbles of quartz and jasperoidal chert that characterize the gravel of the main stream. Sand is rare in alluvium of the North Fork.

\section{Manchester River}

A former tributary of the Teays-age Licking River began the carving of the segment of the present Ohio River valley between Cincinnati and Manchester, Ohio. The tributary, named the Manchester River (see map) by Fowke (1924), has also been called Old Limestone Creek (Fowke, 1898) and Norwood River (Stout and others, 1943). Its course has been described by the above writers, and by Fenneman (1916), Fowke (1933), Leverett (1929), Ray (1974), Teller (1973), and Tight (1903). Most agree that the headwaters were west of a divide near Manchester (fig. 1). In general, those writers show the preglacial Manchester River as having followed the present Ohio River to the mouth of the Little Miami River, and then along the Norwood Trough to Mill Creek the present site of the ancestral Licking River (for localities, see fig. 2). 
Teller (1973, fig. 2), Gibbons and others (1975), and this report show a significant modification in that the Teays-age Manchester left the Ohio River alignment near Ivor, and joined the Licking River within Kentucky. It probably was similar in size and drainage area to the present North Fork.

The Manchester River probably flowed from Manchester within the present Ohio River valley, but then entered Kentucky at Ivor (see map), or possibly on the north side of Mentor at an altitude of at least 200 $\mathrm{m}(660 \mathrm{ft})$ (Stout and others, 1943). It followed Flagg Spring Creek (New Richmond quadrangle) to Twelvemile Creek, and continued northwestward, partly along Twelvemile Creek, partly meandering across that stream's present course. The junction with the Teays-age Licking River was about $3 \mathrm{~km}$ southwest of the present junction of Twelvemile Creek and the Ohio River. The channel of the preglacial river is readily distinguished by the elevation of its thalweg (see map and fig. 3), graded to an accordant junction with the preglacial Licking River. Additionally, brownish chert typical of the Manchester River bedload is present in deposits of the Teays-age Licking River at least as far as downriver as those above Fourmile Creek, downstream from the postulated junction of their preglacial courses. The preglacial course of the Manchester River along Flagg Spring and Twelvemile Creeks was closely followed during the Illinoian by a temporary proglacial bypass channel of the Ohio River (Gibbons and others, 1975).

Silt, clay, and sand of the Manchester River have not been studied. Gravel "consists almost entirely of angular to subangular fragments of brown chert and pebbles of pale-yellow silicified limestone or dolomite; rounded quart $z$ pebbles are locally present but nowhere common" (Gibbons and others, 1975). Although gravel as much as $12 \mathrm{~cm}$ across is present, it is mostly less than $3 \mathrm{~cm}$ across. Glacial pebbles and cobbles are present only where Illinoian Drift impinged upon the deposits (see map). The stream flowed almost entirely upon Ordovician rocks. Strata near Manchester are of youngest Ordovician to Middle Silurian age, and include the Silurian Bisher Limestone and Brassfield Formation, the most probable sources of the silicified limestone and dolomite, and chert, of the Manchester River bedload. The divide at Manchester lies along a low north-south ridge capped in part by resistant Silurian units that include the Brassfield Formation and the Bisher Limestone. The source of quartz pebbles is not known.

\section{DRAINAGE EVOLUTION IN THE GREATER CINCINNATI REGION}

An ancestral Licking River flowed upon or slightly below the present upland surface of the region, if the enigmatic high-level silt and sand deposits of Campbell County, Kentucky, are considered as being fluvial deposits of Tertiary age.

Downcutting and lateral planation by this or a later river system in late Tertiary time initiated the cutting of a broad intermediate valley, presently marked by accordant flat-topped spurs, and caused the deposition of associated lag gravels. Renewed downcutting resulted in the Teays-age evolution of the river. In late Pliocene to earliest Pleistocene time the Teays-age Licking River was incised and entrenched, to the level of the Parker strath of Butts (1904) as used by Desjardins (1934). The preglacial Licking River was then a north-flowing tributary of the Teays-Mahomet river system. It received the flow of the Manchester River in eastern Campbell County. In turn, it joined the northeast-flowing ancestral Kentucky River (Swadley, 1971) near present-day Hamilton, Ohio by the way of the present Mill Creek valley--or, at some undefinable time, perhaps by way of the Little MiamiNorwood Trough route (Durrell, 1961, fig. 2; Teller, 1973, fig 2). In the vicinity of Hamilton, the two rivers joined to form the northeast-flowing Hamilton River (the ancestral Great Miami River) (fig. 2).

In early Pleistocene time an ice sheet overran the Mill Creek segment of the preglacial Licking River in Ohio and invaded northern Kentucky, causing fluvial aggradation and lacustrine deposition along the Teays-age Licking valley in northern Kentucky. Similar effects took place along other streams of the Teays drainage system in Ohio and West Virginia. The Teays-Mahomet system was extensively and permanently disrupted, and during the glaciation most of its tributaries were incorporated into the new Ohio River system. During the glaciation, Lake Claryville probably rose to an altitude of about 267 to $275 \mathrm{~m}$ above current sea level, and perhaps as much as $85 \mathrm{~m}$ above the level of the Parker strath.

Lake Claryville probably began to overflow very soon after its formation, due to the combined influx of Licking River water and, on the downstream end, of water from the newly-forming, throughgoing Ohio River. K. L. Pierce (written communication, April 24, 1979) has suggested that unponded waters from the upper tributaries (east of Cincinnati) of the Teays River merged and flowed westward, south of and roughly parallel to the preglacial Teays-Mahomet River. Upon reaching the now glaciated Cincinnati region, the Ohio River may have flowed as an icemarginal stream upon the highlands of northernmost Kentucky, between the drift and outwash barrier and the north end of Lake Claryville. As suggested above, outwash aggradation may have caused base levels to rise, increasing the altitude of Lake Claryville.

Total original thickness of the Claryville Clay was probably considerably greater than the present maximum of $12 \mathrm{~m}$. Although the lake was draining about as fast as it was being filled from upstream, the time span of Claryville Clay deposition must have been on the order of several tens of thousands of years.

During and for some time after Claryville time the newly-created upper Ohio River flowed westward across northern Kenton County, Kentucky as an icemarginal stream at a level far above the Parker strath. Its gradient was considerably greater than that of the disrupted Teays River or of the modern Ohio River. The westward flow of this Ohio River and of its new tributary, the Licking River of Kentucky, aided the Kentucky River in overtopping and trenching the divide at Madison, Indiana (fig. 1) (Leverett, 1929, p. 46; Swadley, 1971, p. D127; Teller, 1973, p. 3683; Ray, 1974 , p. 39). Since Claryville time the Ohio River system has included the Kentucky River, the now southwest-flowing Great Miami River (reversed from the Hamilton River and captured from the glacially disrupted Teays-Mahomet River), the LickingManchester system, and most or all present upriver tributaries.

The Deep Stage of entrenchment by the Ohio River system, the successor of the Teays-Mahomet 
River system, was inaugurated at some time during or following the early Pleistocene glaciation, and coincided with the drainage of ice-marginal lakes. For the Licking River system in Kentucky, the Deep Stage began upon the draining of Lake Claryville. This may have occurred during a recession (or stagnation) of the early glacier, or after the ice-marginal Ohio River had begun to carve into the highland surface of Kenton County, or perhaps both. A possible remnant of the ice-marginal Ohio River sluiceway, south of the highlevel pre-Illinoian outwash deposits, is the gap (highest present altitude $253 \mathrm{~m}$, or $830 \mathrm{ft}$ ) presently followed by Highland Pike (Covington $71 / 2$ minute quadrangle), the upper part of Pleasant Run Creek, and Dry Creek (see map). Farther south, all present-day cols along the divide between the Kentucky and Licking River basins lie at altitudes above $275 \mathrm{~m}$, the highest postulated high-water level of Lake Claryville. These cols do not appear to have been notched by escaping waters, but only by ongoing headward erosion of hollows.

During an early phase of the Deep Stage in north-central Kentucky, waters of the upper reaches of the Licking River overtopped and breached a low point on the divide at Caldwell, northwest of Butler (see map) (Durrell, 1961, p. 52). Present altitudes along the ridge that formed the divide are well below $275 \mathrm{~m}(900 \mathrm{ft})$. Once through the divide, the waters poured into the preglacial valley of Grassy Creek (see map). The lower channels of Grassy Creek and Cruises Creek, and portions of those of other paleotributaries to the north were scoured, deepened, widened, and locally shifted as the newly diverted throughgoing river cut its new channel downriver to Grants Bend in the Alexandria 7 1/2 minute quadrangle. The now abandoned lowest segment of Grassy Creek became modern Phillips Creek, with its reversed flow away from the Teays-age valley. Deep-Stage erosion removed all Teays-age deposits downstream from Grants Bend, except for the small exposures left above Pooles Creek.

Other possible, perhaps ephemeral outlet of Lake Claryville into the present Licking valley north of the col at Caldwell include, from south to north: Plum and Phillips Creeks (De Mossville quadrangle), low cols below $225 \mathrm{~m}(740 \mathrm{ft})$ in northern De Mossville and southern Alexandria quadrangles, Pond, Fannan, and Scaffold Creeks (Alexandria quadrangle), and the preglacial course through Low Gap. At all these places (except Caldwell and Low Gap), relict deposits of Claryville Clay are present in or near those cols and streams, at short distances from the present valley of the Licking River.

Waters of the Manchester River arm of Lake Claryville may have escaped eastward, and probably aided in the carving of a valley above the present segment of the Ohio River valley between Ivor, Kentucky and the Little Miami River (see map). This new valley might possibly be equated with the alternate route (see above) of Durrell (1961) and Teller (1973). Possible sluiceways include the preglacial cols near Ivor and Mentor, and the present tributaries of the Ohio River that cross low points along the divide between the area of former Lake Claryville and the present Ohio Valley: Twelvemile, Tenmile, and Fourmile Creeks (see map).

Deep-Stage drainage adjustments were entirely different upriver from Butler. Here the Deep-Stage valley in places was entrenched within and below the Claryville Clay and Teays-age deposits and, in other places was established within newly carved segments at varying lateral distances from the Teays-age valley floor (see map).

The result of Deep-Stage drainage changes was a generally straighter and shorter (see fig. 3) Licking River channel throughout the study area. For reasons that remain obscure, the Teays-age channel of the Manchester River within Kentucky was temporarily abandoned in favor of the present channel of the Ohio River between Ivor, Kentucky and the Little Miami River.

During its infancy, the throughgoing Ohio River had been largely unable to carve a valley through the uplands (Teller, 1973, p. 3683 and fig 4.) due to stream baselevels downstream. Much of its later pre-Illinoian history, and that of the now closely involved Licking River, remain conjectural. The sequence of events suggested here differs in certain respects from that proposed by Teller (1973). As the glacier retreated to a position between Cincinnati and Hamilton, Ohio, the upper Ohio River (which now included the former Manchester River) also shifted its course northward, continuing in its role as an essentially valleyless ice-marginal stream, and joined the lower Little Miami River near the mouth ol the latter stream. This course closely approximates the alternate preglacial course shown on the map. This upper segment of the throughgoing Ohio River probably was unable at the time to breach or even overtop the divide at Dayton, Kentucky (fig. 5). Instead, it probably followed a course already available to it: the Norwood Trough segment of the preglacial Little Miami down to Mill Creek (figs. 2 and 5). In doing so, the Ohio scoured away some of the pre-Illinoian glacial deposits recently laid down along this route (to be filled in again by Illinoian glacial deposits). Inasmuch as the Mill Creek route to Hamilton was blocked by the slowly retreating glacier, this upper Ohio River flowed south along the lower Mill Creek valley and joined the rejuvenated Licking River west of Covington. The combined rivers then turned west and succeeded in overtopping, perhaps even in breaching, the divide at Anderson Ferry (figs. 2 and 5), to join the now westward-flowing Kentucky River and the lower Ohio River (Teller, 1973, fig. 6).

As the glacier eventually receded beyond Hamilton, the Anderson Ferry course may have been temporarily abandoned. If so, a major and perhaps long-lived Deep-Stage course of the Ohio River (including the Licking) followed the preglacial course within Ohio of the Licking and lower Little Miami Rivers (but at much lower elevations) to Hamilton, and then the reversed Great Miami-Kentucky course southwestward to and beyond the former Madison divide (fig. 5, and compare with fig. 2 and with Durrell, 1961, fig. 3; Leighton and Ray, 1965, fig 1; and Teller, 1973, fig, 5). This suggested order of events is essentially the reverse of the one indicated by Teller (1973) in his figures 5 and 6 .

By the advent of the Illinoian Glaciation, much of the Licking River was in grade in its new valley which, unlike that of the Ohio River, geographically differed little from its present valley.

During the Illinoian Glaciation, the Ohio River valley was blocked and filled with ice and drift between Silver Grove and Augusta, Kentucky (fig. 1), 
and also further downstream from the Great Miami River to Carrollton, Kentucky (Ray, 1974). As a direct result, the Ohio River flowed as an ice-marginal stream that temporarily occupied and closely followed the largely ice-free valley of the old Manchester River. The lower reaches of Twelvemile Creek were also blocked by ice, and the bypass channel continued in an ice-marginal position along Willow Branch and Fourmile Creek, towards Silver Grove (Gibbons and others, 1975; Ray, 1974, p. 54; Teller, 1973, p. 3685). The route was apparently blocked again north of Mentor (Kohut and others, 1973) and probably also near Silver Grove (Gibbons, 1973) by Illinoian Drift, and a new entry into the bypass channel was opened near Ivor (Ray, 1974, p. 54). This was soon after ponded, as evidenced by the extensive Illinoian lacustrine deposits present north and northwest of Ivor as well as west of Mentor (Luft, 1972; Luft and others, 1973; Gibbons and others, 1975).

The Ohio River also flowed, largely as an ice-marginal stream, from near Silver Grove to Lawrenceburg, Indiana, along its present course through the previously used col at Anderson Ferry. The former great loop through the Norwood Trough and Mill Creek valley to Hamilton was forever abandoned by a major river (Teller, 1973, p. 3684-3685; Ray, 1974, p. 51-55).

The Licking River, blocked by Illinoian outwash near Covington and Newport, aggraded once more over much of its length, filling the valley with alluvium. Illinoian lacustrine deposits are unknown in the Licking valley, except for a small deposit at West Covington (Luft, 1971b) which filled a probable meander scar of the Teays-age Licking River. Lacustrine deposits are present, however, in the downriver continuation of the Deep-Stage Licking valley, the lower Mill Creek valley, where they are mantled by Illinoian Till (Fenneman, 1916, p. 129-131; Durrell, 1961, p. 77-78).

As the Illinoian glacier withdrew from the post-Claryville Manchester-Ohio valley above Cincinnati, the Ohio River returned to the now glacially scoured segment of the valley.

After the glacier receded beyond Hamilton, Ohio, the Hamilton loop was again free of ice. However, it never was reoccupied by a throughgoing river, probably because it was clogged with drift and thus higher than the more southern and direct Anderson Ferry course, which already was being rapidly entrenched into fluvioglacial debris (A. B. Gibbons, oral commun., 1975).

During Sangamonian time, the Licking River was again entrenched to its bedrock (Deep Stage) level (113.5 $\mathrm{m}$, or $372 \mathrm{ft}$, at Cincinnati), flowing upon bedrock and post-Claryville sediments and, near its mouth, upon Illinoian glaciofluvial material. Much of the Illinoian and pre-Illinoian valley fill was scoured from this section of the channel; downstream from Grants Bend, all of the Illinoian fill was removed.

The Wisconsin ice sheet did not reach the Ohio River at Cincinnati. However, much of the Ohio River valley "was a sluiceway for outpourings of melt water and fluvioglacial outwash" (Ray, 1974, p. 58). Two terrace levels, of Tazewell and Cary age as used by Ray (1974, p. 58-65), are recognized at Cincinnati and along the Licking River.

Valley trains of Tazewell age filled much of the Ohio River valley near Cincinnati and blocked the mouths of the Licking River and Fourmile Creek (see map). The resulting outwash terrace stands as high as

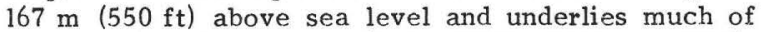
Covington and Newport (Luft, 1971b; Gibbons, 1973). This elevation indicates aggradation of no less than

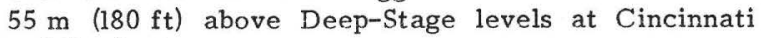
and Covington.

As a result of ponding by outwash near its mouth, slackwater conditions prevailed along the lower Licking during part of Tazewell time. Slackwater deposits grade upstream into extensive fluviatile terrace deposits that extend upriver for a considerable distance beyond the study area. Tazewell-age aggradation of the Licking River and its tributaries was extensive and apparently of long duration.

A period of downcutting followed during which the Licking reestablished a channel that only locally cut down to bedrock through Tazewell-age and older sediments. This stage was followed by a smaller influx of Cary-age outwash (Ray, 1974) into the glaciated Ohio River valley, followed in turn by late-to post-Wisconsin degradation.

Pre-Wisconsin widening of the valley of the main Licking River above Falmouth appears to have lagged behind that of the lower part of the valley. The Wisconsin terraces along that narrower stretch, constricted by limestone-rich walls, had little space within which to develop. They also are less distinct than terraces within the longer established valley of the South Fork and, within the study area, the valley of the North Fork.

Post-Wisconsin downcutting has been the dominant fluvial process over much of the Licking River system. The river, except along its lowest $13 \mathrm{~km}$, now flows largely upon a bedrock floor. Wisconsin terrace deposits and older alluvium of valley sides and meander cores still occupy much of the width of the valley so that the modern floodplain is generally narrow and the river flows between alternating banks of fluvial sediments and of bedrock. It appears that the river preferentially avoids incising into bedrock and enlarging its meanders. Thus, there should be a present and near-future tendency for the river to continue to erode Wisconsin and older sediments and, in the process, straighten its channel by cutting off old meander cores.

\section{REFERENCES CITED}

Blade, L. V., 1978, Geologic map of the Cowan quadrangle, northeastern Kentucky: U.S. Geological Survey Geologic Quadrangle Map GQ-1466.

Bownocker, J. A., 1900, History of the Little Miami River, in The preglacial drainage of Ohio: Ohio State Academy of Science, Special Papers No. 3, p. $32-45$.

Brand, L. S., 1934, Some notes on the Pleistocene history of the Cincinnati region: Ohio Journal of Science, v. 34, p. 67-85.

Butts, Charles, 1904, Description of the Kittanning quadrangle Pennsylvania: U.S. Geological Survey Atlas, Folio 115, 15 p.

Campbell, M. R., 1898, Description of the Richmond quadrangle Kentucky: U.S. Geological Survey Atlas, Folio 46, 4 p. 
Costa, J. E., 1974, Stratigraphic, Morphologic, and Pedologic Evidence of Large Floods in Humid Environments: Geology, v. 2, no. 6, p. 301-303.

Desjardins, Louis, 1934, The preglacial physiography of the Cincinnati region: unpublished M.A. thesis University of Cincinnati, $43 \mathrm{p}$.

Durrell, R. H., 196l, The Pleistocene geology of the Cincinnati area, in Guidebook for field trips, Cincinnati meeting 1961: Geological Society of America, p. 47-57, road log p. 68-73.

1965, Airport roadcuts, in Guidebook for Field Conference G, Great Lakes-Ohio River valley, International Association for Quaternary Research, 7th Congress, U.S.A., 1965: Lincoln, Nebraska, Nebraska Academy of Sciences, p. 6263.

Dury, G. H., and Teller, J. T., 1975, Paleogeomorphic and paleoclimatic implications of "preglacial" meanders in the Cincinnati area: Geology, v. 3, no. 10 , p. 585-586.

Ettensohn, F. R., 1974, The pre-Illinoian lake clays of the Cincinnati region: Ohio Journal of Science, $v$. 74, no. 4, p. 214-226.

Fenneman, N. M., 1914, Preglacial Miami and Kentucky Rivers abs.: Geological Society of America Bulletin, v. 25, p. 85 .

1916, Geology of Cincinnati and vicinity: Ohio Geological Survey, Fourth Series, Bulletin 19, $207 \mathrm{p}$.

1938, Physiography of eastern United States: New York, McGraw-Hill Book Company, 714 p.

Fowke, Gerald, 1898, Preglacial drainage in the vicinity of Cincinnati; its relation to the origin of the modern Ohio River, and its bearing upon the question of the southern limits of the ice-sheet: Denison University, Scientific Laboratories Bulletin, v. 1l, Article 1, p. 1-10.

1900 , Preglacial drainage conditions in the vicinity of Cincinnati, in The preglacial drainage of Ohio: Ohio State Academy of Science, Special Papers No. 3, p. 68-75.

1924, The genesis of the Ohio River: Indiana Academy of Science Proceedings, v. 34, p. 81-102. 1933, The evolution of the Ohio River: Indianapolis, Indiana, The Hollenback Press, 273 p.

Gibbons, A. B., 1971, Geologic map of the Alexandria quadrangle, Campbell and Kenton Counties, Kentucky: U.S. Geological Survey Geologic Quadrangle Map GQ-926.

1973, Geologic map of parts of Newport and Withamsville quadrangles, Campbell and Kenton Counties, Kentucky: U.S. Geological Survey Geologic Quadrangle Map GQ-1072.

Gibbons, A. B., Kohut, J. J., and Weiss, M. P., 1975, Geologic map of the New Richmond quadrangle, Kentucky-Ohio: U.S. Geological Survey Geologic Quadrangle Map GQ-1228.

Goldthwait, R. P., White, G. W., and Forsyth, J. L., 1967, Glacial map of Ohio: U.S. Geological Survey Miscellaneous Investigations Series Map I-316.

Hays, F. R., 1951, The Pleistocene history of the Cincinnati area: Compass, v. 28, no, 2 p. 131-139.

Horberg, Leland, 1945, A major buried valley in eastcentral Illinois and its regional relationships: Journal of Geology, v. 53, no. 5, p. 349-359.

Hoyer, M. C., 1972, Remanent magnetism of Minford Silt, southern Ohio: Geological Society of America, Abstracts with Programs, v. 4, no. 7, p. 544.
1977, Quaternary valley fill of the abandoned Teays drainage system in southern Ohio: Dissertation Abstracts International, v. 37, no. 8, p. 3825-B.

Hylbert, D. K., and Philley, J. C., 1971, Geologic map of the Bangor quadrangle, east-central Kentucky: U.S. Geological Survey Geologic Quadrangle Map GQ-947.

Jillson, W. R., 1963, Delineation of the Mesozoic course of the Kentucky River across the inner Bluegrass Region of the State: Frankfort, Kentucky, Roberts Printing Company, 24 p.

Klaer, F. H., Jr., and Thompson, D. G., 1948, Groundwater resources of the Cincinnati area, Butler and Hamilton Counties, Ohio: U.S. Geological Survey Water-Supply Paper 999, 168 p.

Kohut, J. J., Weiss, M. P., and Luft, S. J., 1973, Geologic map of the Laurel quadrangle, OhioKentucky: U.S. Geological Survey Geologic Quadrangle Map GQ-1075.

Leighton, M. M., and Ray, L. L., 1965, Glacial deposits of Nebraskan and Kansan age in northern Kentucky, in Geological Survey Research 1965: U.S. Geological Survey Professional Paper 525-B, p. B126-B131.

Leverett, Frank, 1902, Glacial formations and drainage features of the Erie and Ohio basins: U.S. Geological Survey Monograph 41, 802 p. 1929, The Pleistocene of northern Kentucky: Kentucky Geological Survey, series 6, v. 31, p. 180.

Luft, S. J., 1969, Geologic map of the Independence quadrangle, Kenton and Boone Counties, Kentucky: U.S. Geological Survey Geologic Quadrangle Map GQ-785.

1970, Geologic map of the De Mossville quadrangle, north-central Kentucky: U.S. Geological Survey Geologic Quadrangle Map GQ-862.

1971a, Geologic map of the Goforth quadrangle, Pendleton and Grant Counties, Kentucky: U.S. Geological Survey Geologic Quadrangle Map GQ-925.

1971b, Geologic map of part of the Covington quadrangle, northern Kentucky: U.S. Geological Survey Geologic Quadrangle Map GQ-955.

1972a, Geologic map of the Butler quadrangle, Pendleton and Campbell Counties, Kentucky: U.S. Geological Survey Geologic Quadrangle Map GQ-982.

$1972 \mathrm{~b}$, Geologic map of the Falmouth quadrangle, Pendleton County, Kentucky: U.S. Geological Survey Geologic Quadrangle Map GQ-1037.

1974, Geologic map of the Kelat quadrangle, Harrison and Pendleton Counties, Kentucky: U.S. Geological Survey Geologic Quadrangle Map GQ1172.

1975, Geologic map of the Berry quadrangle, north-central Kentucky: U.S. Geological Survey Geologic Quadrangle Map GQ-1284.

1976, Geologic map of the Claysville quadrangle, northeastern Kentucky: U.S. Geological Survey Geologic Quadrangle Map GQ-1341.

Luft, S. J., Osborne, R. H., and Weiss, M. P., 1973, Geologic map of the Moscow quadrangle, Ohio-Kentucky: U.S. Geological Survey Geologic Quadrangle Map GQ-1069.

Malott, C. A., 1920, Static rejuvenation: Science, new series, v. 52, no. 1338, p. 182-183. 
Malott, C. A., 1922, The physiography of Indiana, in Handbook of Indiana geology: Indiana Department of Conservation, Division of Geology Publication 21, p. 59-256.

McDowell, R. C., 1976, Geologic map of the Colfax quadrangle, east-central Kentucky: U.S. Geological Survey Geologic Quadrangle Map GQ-1332.

Miller, A. M., 1895, High level gravel and loam deposits of Kentucky rivers: American Geologist, v. 16, p. 281-287.

Neff, J. R., Blankenship, T. L., Bonnett, R. B., and Scrudato, R. J., 1970, Teays River and lake deposits: Geological Society of America Abstracts with Programs, v. 2, no. 3, p. 233-234.

Norris, S. E., and Spicer, H. C., 1958, Geological and geophysical study of the preglacial Teays Valley in west-central Ohio: U.S. Geological Survey WaterSupply Paper 1460-E, p. 199-232.

Price, W. E., Jr., 1964, Geology and hydrology of alluvial deposits along the Ohio River between Newport and Warsaw, Kentucky: U.S. Geological Survey Hydrologic Investigations Atlas HA-98.

Ray, L. L., 1965, Kentucky, in Guidebook for Field Conference G, Great Lakes-Ohio River valley, International Association for Quaternary Research (INQUA), 7th Congress, U.S.A., 1965: Lincoln, Nebraska, Nebraska Academy of Sciences, p. 5363.

1974, Geomorphology and Quaternary geology of the glaciated Ohio River valley-A reconnaissance study: U.S. Geological Survey Professional Paper 826, $77 \mathrm{p}$.

Rhodehamel, E. C., and Carlston, C. W., 1963, Geologic history of the Teays Valley in West Virginia: Geological Society of America Bulletin, v. 74, p. 251-273.

Ritter, D. F., 1975, Stratigraphic implications of coarse-grained gravel deposited as overbank sediment, southern Illinois: Journal of Geology, v. 83 , no. 5 , p. $645-650$.

Schaber, G. G., 1962, The weathered, high-level sands and silts of northern Kenton County, Kentucky: Compass, v. 40, no. 1, p. 27-38.

Squier, G. H., 1883, Erratic pebbles in the Licking valley: Science, v. 2, p. 436.

Stout, W. E., and Schaaf, Downs, 1931, Minford silts of Southern Ohio: Geological Society of America Bulletin, v. 42, no. 3, p. 663-672.

Stout, W. E., Ver Steeg, Karl, and Lamb, G. F., 1943, Geology of water in Ohio (a basic report): Ohio Geological Survey, Fourth Series, Bulletin 44, $694 \mathrm{p}$.
Swadley, W C, 1971, The preglacial Kentucky River of northern Kentucky, in Geological Survey Research 1971: U.S. Geological Survey Professional Paper 750-D, p. D127-D131.

Teller, J. T., 1962, The pre-Illinoian upland sands of the Alexandria, Kentucky, area: Compass, v. 40, no. 1, p. 39-49.

Teller, J. T., 1973, Preglacial (Teays) and Early Glacial Drainage in the Cincinnati Area, Ohio, Kentucky, and Indiana: Geological Society of America Bulletin, v. 84, p. 3677-3688.

Thornbury, W. D., 1965, Regional geomorphology of the United States: New York, John Wiley and Sons, Inc., $609 \mathrm{p}$.

Tight, W. 'G., 1903, Drainage modifications in southeastern Ohio and adjacent parts of West Virginia and Kentucky: U.S. Geological Survey Professional Paper 13, 111 p.

Ver Steeg, Karl, 1936, The buried topography of western Ohio: Journal of Geology, v. 44, no. 8, p. 918-939.

Walker, E. H., 1953, Geology and ground-water resources of the Covington-Newport alluvial area, Kentucky: U.S. Geological Survey Circular 240, $26 \mathrm{p}$.

1957, The deep channel and alluvial deposits of the Ohio Valley in Kentucky: U.S. Geological Survey Water-Supply Paper 141l, 25 p.

Wallace, R. M., 1975, Geologic map of the Shady Nook quadrangle, northeastern Kentucky: U.S. Geological Survey Geologic Quadrangle Map GQ1261.

1976a, Geologic map of the Breckinridge quadrangle, Harrison and Scott Counties, Kentucky: U.S. Geological Survey Geologic Quadrangle Map GQ-1344.

$1976 \mathrm{~b}$, Geologic map of the Cynthiana quadrangle, Harrison County, Kentucky: U.S. Geological Survey Geologic Quadrangle Map GQ-1333. 1978, Geologic map of the Piqua quadrangle, northeastern Kentucky: U.S. Geological Survey Geologic Quadrangle Map GQ-1425.

Wayne, W. J., 1952, Pleistocene evolution of the Ohio and Wabash valleys: Journal of Geology, v. 60, no. 6, p. 575-585.

Wright, G. F., 1884, The glacial boundary in Ohio, Indiana, and Kentucky: Cleveland, Western Reserve Historical Society, Tract 2, p. 193-268. 